\title{
Presence of the alien chinese pond mussel Anodonta woodiana (Lea, 1834) (Bivalvia, Unionidae) in the Iberian Peninsula
}

\author{
Q. Pou-Rovira ${ }^{1}$, R. Araujo 2 , D. Boix ${ }^{3 *}$, M. Clavero ${ }^{4}$, C. Feo ${ }^{5}$, M. Ordeix ${ }^{6}$ \& L. Zamora ${ }^{3}$
}

Freshwater bivalve invasions are nowadays a global phenomenon and some species, such as the zebra mussel, Dreissena polymorpha (Pallas, 1771), are listed amongst the most pervasive invaders in the world (Lowe et al., 2000). Bivalves are considered key species in aquatic ecosystems, being capable of controlling and transforming their structure and functioning through their filtering activity (Strayer et al., 1999). Thus, the establishment of alien bivalves often entails severe consequences at multiple levels in the newly occupied aquatic environments. These include dramatic changes in the diversity and abundance of benthic and planctonic communities, creation of new habitats, alterations in the rates of ecosystem processes or interferences with human infrastructures and water uses, frequently involving a large economic cost (Strayer et al., 1999; Karateyev et al., 2005; Ward \& Ricciardi, 2007). To date, there were three species of alien bivalves reported as having established populations in the Iberian Peninsula (García Berthou et al., 2007), two of them inhabiting freshwaters [Asian clam, Corbicula fluminea (Müller, 1774), and zebra mussel] and the third one, Mytilopsis leucophaeta (Conrad, 1831), occupying brackish and estuarine waters.

Native freshwater bivalves are a highly threatened group which has undergone a global decline in the last decades (Lydeard, et al., 2004; Bogan, 2008). The Iberian freshwater bivalve fauna has also faced serious declines and many local extinction events have been recorded. Moreover, the Iberian Peninsula bears one of the last populations of the critically endangered giant European freshwater pearl mussel, Margaritifera auricularia (Spengler, 1793), a species that had a wide European distribution range in the past (Araujo \& Ramos, 2000). Although habitat modification and destruction have sometimes been identified as primary drivers of freshwater bivalve declines (e.g. Bogan, 2008), some works have linked the establishment of alien species to the rarefaction and extinction of native bivalve populations (Ricciardi et al., 1998). Thus, the spread of invasive bivalves should not only be judged by their ecosystem effects but also by their role in biodiversity loss processes.

Anodonta $(=$ Sinanodonta $)$ woodiana is probably the unionoid that has been most widely introduced outside its natural distribution area. It is a large mussel species (reaching $30 \mathrm{~cm}$ ) native to Oriental Asia, including south-eastern Russia, China, Cambodia, Thailand, Malaysia, Japan and Taiwan (Tabe et al., 1994; Watters, 1997). In Europe, A. woodiana was first recorded in Romania in 1979 and later in 1982 in France and in 1984 in Hungary (Watters, 1997; Beran, 2008) and nowadays it is known to occur in Yugoslavia, Serbia, Austria, Slovakia, Czech Republic, Poland, Holland, Germany, Ukraine, Italy (Kraszewski, 2007; de Vico et al., 2007; Beran, 2008) and Belgium (J. Conde, pers. comm.). Its presence is known in Java, Sumatra and other islands since 1969, in Costa Rica since 1994 and in Hispaniola since 1982 (Watters, 1997). All this human-mediated spread was probably related to the introduction of commercially exploited fish species, many of them being suspected hosts for the glochidia of $A$. woodiana (Watters, 1997). The dissemination of $A$. woodiana can be made by the

SORELLÓ, Estudis al Medi Aquàtic; Jocs Olímpics 3er, 1a; 17003 - Girona, Spain

Museo Nacional de Ciencias Naturales; José Gutérrez Abascal 2; 28006 - Madrid, Spain

Institut d'Ecologia Aquàtica, Universitat de Girona; Facultat de Ciències, campus Montilivi; 17071 - Girona, Spain

Grup d'Ecologia del Paisatge, Àrea de Biodiversitat, Centre Tecnològic Forestal de Catalunya; Pujada del Seminari s/n; Solsona, Spain

Museu Darder-Espai d'Interpretació de l'Estany; Plaça dels Estudis, 2; 17820 Banyoles, Spain

Centre d'Estudis dels Rius Mediterranis (CERM), Passeig del Ter s/n, 08560 Manlleu, Spain

* Corresponding author (Phone: +34 972418 466; E-mail: dani.boix@udg.es) 
spreading of mussels and/or infested fishes. The only available genetic analysis made in Europe, coming from the pioneer population in Poland, suggests either a massive colonization by genetically diverse individuals or a multiple colonization by founder populations coming from various water bodies (Soroka, 2006).

The first findings of $A$. woodiana specimens in the Iberian Peninsula were made in 2006. Several Anodonta populations were located in the framework of a study on freshwater fish communities in the lower section of the Ter River (Pou Rovira et al., 2007). Among the specimens two morphotypes were easily distinguished: one corresponded to the native $A$. anatina, while the other was identified as A. woodiana (Figure 1). In July 2007, several specimens of $A$. woodiana, also mixed with specimens of $A$. anatina, were found in one channel which transfers water from the Ter to the Daró River. We then examined unionid valves that had been previously collected from the Ter and other neighboring river basins, which were kept at the University of Girona and in the Darder Museum (natural history museum of Banyoles), in order to identify any possible previous unnoticed collection of $A$. woodiana in the area. None of the collection specimens were identified as $A$. woodiana. However, in June 2008 new specimens of $A$. woodiana from the Fluvià River were sent to the Darder Museum. Thus, the species presently is known to occur in three north-eastern Iberian river basins: Ter, Fluvià and Daró (Figure 2).

Four native freshwater mussel species are known to inhabit Ter and Fluvià rivers: Anodonta anatina (Linnaeus, 1758), Potomida littoralis (Cuvier, 1798), Unio mancus Lamarck 1819 and Unio cf. aleroni Companyó \& Massot, 1865 (Bofill et al., 1921; Altaba, 1992: Araujo, pers. obs.). All four species have undergone a strong decline in the area and known populations are nowadays scarce (Boix et al., 2001; Franch et al., 2003). Due to its unusually high growth ratio and reproductive potential, $A$. woodiana can become a serious competitor of native bivalves, aggravating their already poor conservation status. In fact, $A$. woodiana has become the dominant species among the freshwater mussels in several of the invaded countries (e.g. Kraszewski, 2007; Beran, 2008). Moreover, the species can attain large densities (up to 20-25 thousand $\mathrm{kg} \cdot \mathrm{ha}^{-1}$; after Soroka \& Zdanowski, 2001) and can be responsible for profound changes in the bottom community composition and the ecological equilibrium of the natural environment (Soroka \& Zdanowski, 2001). At least in the lower Ter, A. woodiana coexists with another invasive bivalve, the Asian clam Corbicula fluminea, a situation that could have increased impacts on aquatic environments and native mussel populations due to synergistic effects.

Fish communities in the lower sections of the Ter, Daró and Fluvià are largely dominated by invasive

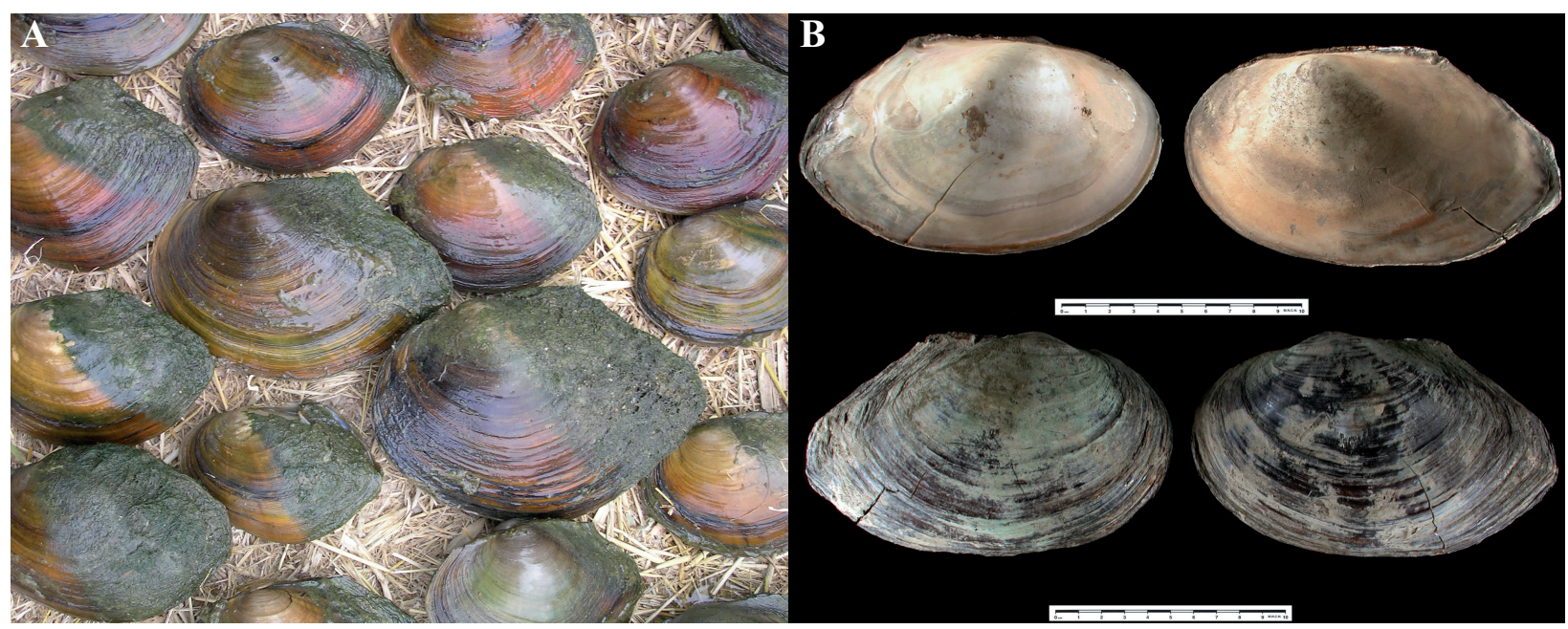

Fig. 1.-A) Living specimens of Anodonta (= Sinanodonta) woodiana collected in the lower reaches of the River Ter. B) Internal and external views of the shell of the species, from a dead individual collected in the same area.

Fig. 1.- A) Especímenes vivos de Anodonta (= Sinanodonta) woodiana recolectados en la tramo bajo del río Ter. B) Visiones internas y externas de las valvas de individuos muertos recolectados en la misma área. 


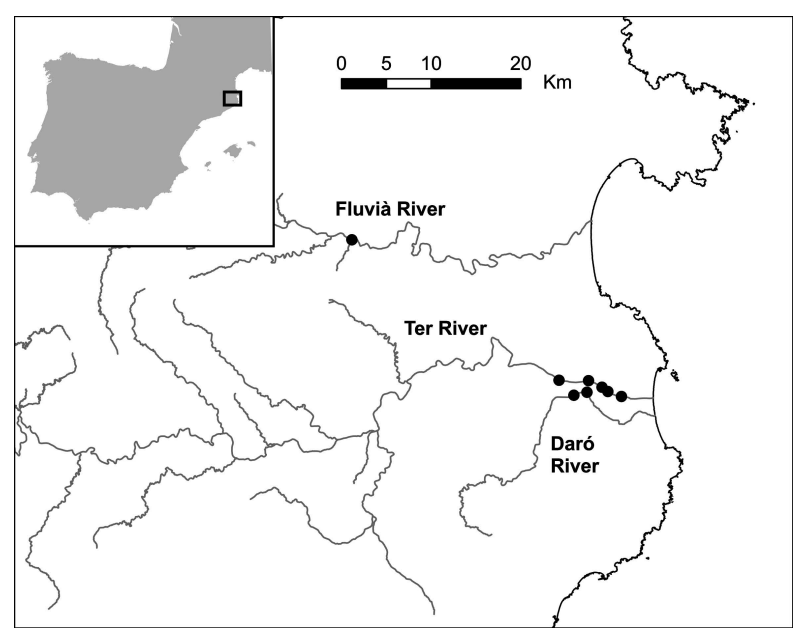

Fig. 2. - Locations of $A$. woodiana (black dots) in the Fluvià, Ter and Daró river basins (NE Iberian Peninsula).

Fig. 2.- Localizaciones de $A$. woodiana (puntos negros) en las cuencas fluviales del Fluvià, Ter y Daró (NE Península Ibérica).

fish species (e.g. Pou-Rovira et al. 2007), such as mosquitofish (Gambusia holbrooki), common carp (Cyprinus carpio), goldfish (Carassius auratus), pumpkinseed sunfish (Lepomis gibbosus) or the Ebro barbel (Barbus graellsii, a translocated Iberian species). This situation should favor the dominance of $A$. woodiana over native mussels and the expansion of the species within river basins. At least mosquitofish has been shown to be an excellent host for the glochidia of $A$. woodiana, with prevalence reaching $100 \%$ and a high number of glochidia per fish (Dudgeon \& Morton, 1984). Other invasive fish species abundant in the area (e.g. common carp) are also considered potential hosts of $A$. woodiana glochidia (Watters, 1997). In contrast, native freshwater mussels strictly depend on native fish during their parasitic phase, although in the study area they could also use the translocated Ebro barbel as host (Gómez \& Araujo, 2008). According to these authors, other possible hosts present in the area include the freshwater blenny (Salaria fluviatilis) and the Catalan chub (Squalius laietanus), but both species are nowadays rare and declining in the lower reaches of Ter, Fluvià and Daró rivers (Pou-Rovira et al., 2007). The introduction of exotic fish species is nowadays one of the big threats for the native naiads because of the competition with the native fish species which act as hosts of the native mussels.

After the impressively rapid expansion of $A$. woodiana in Europe, it seems clear that there is a large risk of interbasin spread of the species within the Iberian Peninsula. Moreover, Clavero \& GarcíaBerthou (2006) showed that north-eastern Iberian basins are the main entry point of invasive freshwater fish species into the Iberian Peninsula, which later colonize other basins through human-mediated jump dispersals. The explosive diffusion of the bleak (Alburnus alburnus) across Iberian basins (Vinyoles et al., 2007) is a clear example of this process. Interbasin water connections may also play an important role in the expansion of $A$. woodiana. In fact, the presence of the species in the Daró River can be related to the direct connection of its lower section with the Ter River, through a web of irrigation channels (Pou-Rovira et al., 2007). The expansion of $A$. woodiana to the Ebro basin is likely to occur, since numerous invasive species exchanges have been recorded between this and other northeastern Iberian basins (mainly Ter; e.g. Franch et al., 2008). If this occurs, it could have pernicious consequences for the conservation of one of the last world populations of Margaritifera auricularia.

\section{ACKNOWLEDGEMENTS}

We are grateful to M. A. Ramos for her comments on the manuscript.

\section{References}

AltaBA, C. R., 1992. La distribució geogràfica i ecològica dels bivalves d'aigua dolça recents dels Països Catalans. Butlletí de la Institució Catalana d'Història Natural, 60(Secció de Zoologia, 9): 77-103.

Araujo, R. \& Ramos, M. A., 2000. Status and conservation of the relict giant European freshwater pearl mussel Margaritifera auricularia (Spengler, 1793). Biological Conservation, 96: 233-239.

BERAN, L., 2008. Expansion of Sinanodonta woodiana (Lea, 1834) (Bivalvia: Unionidae) in the Czech Republic. Aquatic Invasions, 3(1): 91-94.

Bofill, A., HaAs, F. \& Aguilar-Amat, J. B., 1921. Estudi sobre la malacologia de les valls pirenaiques. Conques del Besòs, Ter, Fluvià, Muga i litorals intermitjes. Treballs del Museu de Ciències Naturals de Barcelona, 3: $1-1241$.

Bogan, A. E., 2008. Global diversity of freshwater mussels (Mollusca, Bivalvia) in freshwater. Hydrobiologia, 595: 139-147.

Boix, D., SAlA, J. \& FEO, C., 2002. Localització d'una població viable d'Unio aleroni (Unionidae, Bivalvia) a la conca del Fluvià i estat del coneixement de les nàiades al Pla de l'Estany. Scientia gerundensis, 25: 27-29.

Clavero, M. \& García-Berthou, E., 2006. Homogenization dynamics and introduction routes of invasive 
freshwater fish in the Iberian Peninsula. Ecological Applications, 6: 2313-2324.

De Vico, G., Maio, N. \& Castagnolo, L., 2007. Prime segnalazione di Anodonta (Sinanodonta) woodiana (Lea, 1834) (Mollusca: Bivalvia: Unionidae) per il Sud Italia. Notiziario S.I.M., 25(1-4): 23-25.

Dudgeon, D. \& Morton, B., 1984. Site selection and attachment duration of Anodonta woodiana (Bivalvia, Unionacea) glochidia on fish hosts. Journal of Zoology, 204, 355-362.

Franch, M., BoIX, D. \& SALA, J., 2003. Localitzacions de Nàiades (Mollusca: Bivalvia: Unionoida) a les conques de la Muga, de la Tordera i del Ter. Scientia gerundensis, 26: 5-7.

Franch, N., Clavero, M., Garrido, M., Gaya, N., López, V., Pou-Rovira, Q. \& Queral, J. M., 2008. On the establishment and range expansion of oriental weatherfish (Misgurnus anguillicaudatus) in NE Iberian Peninsula. Biological Invasions, 10: 1327-1331.

García-Berthou, E., Boix, D. \& Clavero, M., 2007. Non-indigenous animal species naturalized in Iberian inland waters. In: F. Gherardi (ed.). Biological Invaders in Inland Waters. Springer. Dordrecht: 123-140.

Gómez, I. \& Araujo, R., 2008. Channels and ditches as the last shelter for freshwater mussels. The case of M. auricularia and other naiads at the mid Ebro River basin, Spain. Aquatic Conservation: Marine and Freshwater Ecosystems, 18: 658-670.

Karatayev, A. Y., Burlakova, L. E. \& Padilla D. K., 2005. Contrasting distribution and impacts of two freshwater exotic suspension feeders, Dreissena polymorpha and Corbicula fluminea. In: R. Dame and S. Olenin (eds.). The Comparative Roles of Suspension Feeders in Ecosystems. NATO Science Series: IV - Earth and Environmental Sciences. Springer. Dordrecht: 239-262.

KrASZEWSKI, A., 2007. The continuing expansion of Sinanodonta woodiana (Lea, 1834) (Bivalvia: Unionidae) in Poland and Europe. Folia Malacologica, 15(2): 65-69.

Lowe, S., Browne, M., Boudjelas, S. \& De Poorter, M., 2000. 100 of the World's Worst Invasive Alien Species. A selection from the Global Invasive Species Database. Invasive Species Specialist Group (ISSG) Species Survival Commission (SSC) World Conservation Union (IUCN). 12 pp. (Available: www.issg.org/booklet.pdf).

Lydeard, C., Cowie, R. H., Ponder, W. F., Bogan, A. E., Bouchet, P., Clarck, S. A., Cummings, K. S., Frest, T. J., Gargominy, O., Herbert, D. G., Hershler, R., Perez, K. E., Roth, B., Seddon, M., Strong, E. E. \& Thompson, F. G., 2004. The global decline of nonmarine mollusks. BioScience, 54(4): 321-330.
Pou-Rovira, Q., Clavero, M. \& Zamora, L., 2007. Els peixos de les Gavarres $i$ entorns. Consorci de les Gavarres. Monells, Girona. 135 pp.

Ricciardi, A., Neves, R. J. \& Rasmussen J. B., 1998. Impending extinctions of North American freshwater mussels (Unionoida) following the zebra mussel (Dreissena polymorpha) invasion. Journal of Animal Ecology, 67: 613-619.

SoroKA, M., 2006. Genetic structure of the Chinese clam Anodonta woodiana Lea, 1834. Folia Malacologica, 14(4): 169-178.

SOROKA, M. \& ZDANOWSKI, B., 2001. Morphological and genetic variability of the population of Anodonta woodiana (Lea, 1834) occurring in the heated Konin Lakes system. Archives of Polish Fisheries, 9(2): 239-252.

Strayer D. L., Caraco N. F., Cole J. F., Findlay S. \& PACE M. L., 1999. Transformation of freshwater ecosystems by bivalves. Bioscience, 49: 19-27.

Tabe, M., Fukuhara, S. \& Nagata, Y., 1994. Genetic differentiation between two types of Swan mussel, Anodonta woodiana, in Japan. Venus, 53(1): 29-35.

Vinyoles, D., Robalo, J. I., De SostoA, A., Almodóvar, A. \& ElvirA, B., 2007. Spread of the alien bleak Alburnus alburnus (Linnaeus, 1758) (Actinopterygii, Cyprinidae) in the Iberian Peninsula: the role of reservoirs. Graellsia, 63: 101-110.

WARD, J. M. \& RiCCIARDI, A., 2007. Impacts of Dreissena invasions on benthic macroinvertebrate communities: a meta-analysis. Diversity and Distributions, 13: $155-165$.

WAtTERS, G. T., 1997. A synthesis and review of the expanding range of the Asian freshwater mussel Anodonta woodiana (Lea, 1834) (Bivalvia: Unionidae). The Veliger, 40(2): 152-156.
Recibido, 27-X-2008 Aceptado, 13-V-2009 Publicado, 29-VI-2009 